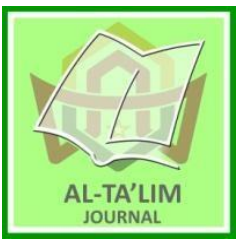

AL-TA'LIM JOURNAL, 28 (3), 2021, (223-233)

(Print ISSN 1410-7546 Online ISSN 2355-7893)

Available online at http://journal.tarbiyahiainib.ac.id/index.php/attalim

\title{
New Students' Self-Adjustment at Ar-Risalah Islamic Junior High School: Roles and Supporting Factors
}

Received: $23^{\text {th }}$ September 2021; Revised: $26^{\text {th }}$ November 2021; Accepted: $30^{\text {nd }}$ November 2021

Permalink/DOI: $\underline{\text { http://dx.doi.org/10.15548/jt.v28i3.736 }}$

\section{Hasneli*)}

Universitas Islam Negeri Imam Bonjol

Padang, Indonesia.

E-mail. hasneli@uinib.ac.id

\section{Alfaiz}

Sekolah Tinggi Keguruan dan Ilmu Pendidikan PGRI Sumatera Barat. Indonesia.

E-mail: alfaiz.science.icp@gmail.com

\section{Augusto Da Costa}

Instituto Superior Cristal, Timor Leste E-mail. acostas3bk2015@gmail.com

\section{*) Corresponding Author}

\begin{abstract}
The purpose of this research is to determine teachers' roles in improving students' self-adjustment and its supporting factors at Ar-Risalah Islamic Junior High School, Padang, Indonesia. This is qualitative descriptive research with data collected from teachers, students, principals, and other school officials through interview, observation, and documentation. The data collected were analyzed using reduction and triangulation processes. The result showed that the teacher had expertise as a motivator to support and trigger the student enthusiasm in adapting and learning new materials at school. Meanwhile, the inhibiting factors of the selfadjustment process were parents that have not been able to let their children go to boarding schools and teachers without psychological backgrounds, because this background are needed for better approach and intervention for children to make them enthusiasm in learning in boarding school.
\end{abstract}

Keywords: Supports; self-adjustment; adaptation; teacher; school

How to Cite: Hasneli, H., Alfaiz, A., \& Costa, A. (2021). New Students' Self-Adjustment at Ar-Risalah Islamic Junior High School: Roles and Supporting Factors. Al-Ta lim Journal, 28(3). doi:https://doi.org/10.15548/jt.v28i3.736

\section{INTRODUCTION}

Self-adjustment is an individual's ability to understand and take certain actions as well as get acclimatized to the group's expectations (da Costa et al., 2018; Japar, 2014; Li et al., 2017; Noviandari \& Mursidi, 2019). Meanwhile, good self-adjustment is the ability to manage oneself while facing these changes quickly. According to GimenezSerrano et al. (2021), adjustment constitutes 2 aspects, namely personal and social. Personal adjustment is individuals' acceptance of their personality, meaning that they tend to accept their existence irrespective of their expectations. Meanwhile, the social adjustment occurs within the scope of societal relations in which the individual lives and interacts namely family, school, or playmates.

Every human being engages in selfadjustments daily to achieve balance, especially in a new atmosphere such as school, dormitory, and other places ( $\mathrm{Na}$ et al., 2015). Therefore, students are bound to fail in adaptation without the teachers' help in the new school environment. They need to be able to adapt and become mature in character formation to become skilled and accepted by the environment (Karadağ et al., 2020; Naziah et al., 2020). In educational institutions, the teacher's spirit is perceived as the determinant 
of the learning processes in terms of changing the students' character. Accordingly, the teachers are the spearhead in such processes.

Government Regulation number 74 of 2008 concerning Teachers and Lecturers in Chapter I, Article 1 states that "Educators are professionals with the main task of teaching, guiding, directing, training, assessing, and evaluating students from early childhood to, elementary, and secondary education". Based on this regulation, teachers are not only tasked with delivering subject matter in the classroom, rather, they are also responsible for guiding, educating, and ensuring the students are independent.

Kadafi et al. (2021) stated that the tasks and roles of educators involve carrying out scientific education because it has a significant influence on the formation of personality and human dignity. However, in general, parents and Muslim educators are also responsible because it is in sync with their duties, namely providing education from a human perspective. This is realized by maintaining the students' human nature as given by God (R. H. R. Alfaiz et al., 2020; Ikhwan et al., 2020; Rahawarin et al., 2020; Sokip et al., 2019). Sultana (2014) reported that the code of ethics for teaching is that teachers need to love their students as much as they love themselves. This simply means that they have to assume that the students are part of themselves. Furthermore, teachers need to use their position and wealth of knowledge to help students fulfill their educational needs. For instance, the students need to be visited or assisted when sick and run out of supplies. This illustrates that teachers are advised to treat them with love (Anand et al., 2021; Baeten \& Simons, 2014).

Self-adjusting means accepting people as they are, irrespective of all their weaknesses and strengths. Besides, there is a need to understand and evaluate other individuals objectively (Metzger, 2014; St-Charles et al., 2015). Meanwhile, certain privileges need to be recognized despite their shortcomings (Alfaiz et al., 2019). Furthermore, people have to realize that they are part of the community or environment, therefore it is important to adapt to the social rules, regulations, laws, customs, and religious teachings. According to this definition, mentally healthy individuals are able to control all factors to overcome any form of agitation, such as emotional pressures and frustration.

Modern Islamic Boarding School is an educational institution with accommodation facilities. All students live in the dormitory and comply with all the rules (Halik, 2016; Musaddad, 2021; Pasi et al., 2020). Those accustomed to the caress and attention of their parents are bound to feel uncomfortable certainly and have difficulty adapting to the new atmosphere. Therefore, the research location is Ar-Risalah Islamic College Junior High School, located in Air Dingin, Balai Gadang Village, Koto Tangah Sub-district, Padang, Indonesia.

Based on the initial observations carried out on August 24, 2014, at the school, most of the new students looked confused and cried, while some others were self-secluded and seemed unable to mingle with other students. In this context, guidance from the teachers both in the dormitory and classroom is needed for the students' self-adjustment process. A certain student hugged, joked, and played badminton with several others and the teacher on that particular day.

One of the caregivers that taught at the Ar-Risalah Islamic College Junior High School Padang was also interviewed. It was discovered that generally, new students usually obey commands without much argument. However, in about a week, they start to hang out with their friends, thereby revealing their personalities related to their dependence on their parents. Usman \& Hasna (2019) carried out several studies on students' self-adjustment and self-efficacy in the educational environment, which stated that an increase in self-adjustment leads to a rise in selfconfidence, thereby driving to a positive selfefficacy. However, no research has been carried out on teachers' role in improving selfadjustment in the context of learning performance (Hasanah \& Usman, 2020; Toharudin et al., 2019). This research aims to discover a teachers' role in improving selfadjustment of student's performance and also 
factor that influence this process in Ar-Risalah Islamic Colege Junior High School Padang.

Ar-Risalah Islamic College Junior High School Padang has programs and tips to guide students on ways to adapt to the dormitory and school life. The guidance supports those that initially encountered problems during self-adjustment, properly blending with the environment, controlling their emotions, improving learning enthusiasm, encouraging themselves and others, and adequately carrying out their responsibilities and school assignments (Japar, 2014). Therefore, it is necessary to understand the teachers' roles at the Ar-Risalah Islamic College Junior High School Padang to improve students' self-adjustment. Based on these explanations, the research question is centered on the roles and strategies adopted by teachers in improving students' self-adjustment process irrespective of the supporting and hindering factors.

\section{METHOD}

\section{Research Design}

Qualitative research is a scientific process used to understand human problems in a social context by creating a comprehensive and complex description and reporting detailed views of information sources in a natural setting without any intervention (Anggito \& Setiawan, 2018; Moleong, 2021). The phenomenology model was adopted to uncover, examine, and understand any unique context experienced by individuals (Rukin, 2019).

\section{Research Instruments}

Instrumentation involves observation guidelines, carried out to directly recognize the strategies adopted by the teachers both in the dormitory and school, to help the selfadjustment process of new students at SMP Perguruan Islam Ar-Risalah Padang. An open interview process was also carried out to obtain detailed and essential information. Moreover, documentation was performed to complete the qualitative research findings process as real field data.

\section{Data Analysis}

The data were analyzed using an interactive model designed by Miles and Huberman. This was continuously reviewed until the information became saturated. In addition, the interactive model consists of 3 stages, namely data collection, reduction, and display (Sugiyono, 2015). The collection process is carried out before, during, and at the end of the study. Ideally, this procedure is performed based on the research concept. The data were collected through observations, interviews, and documentation. Data reduction is essentially the process of merging all uniform information into a written form (script).

\section{RESULT AND DISCUSSION}

Ar-Risalah Islamic College Junior High School is part of the Ar-Risalah Islamic College, which provides continuing education for 6 (six) years with boarding facilities (SMP or Junior High School and Madrasah Aliyah or Islamic Senior High School). The internal curriculum is affiliated with the Ministry of Education and it refers to those at the same level in the Middle East. Therefore, graduates are expected to compete in general sciences by adhering to the universal Islamic principles.

One of the prioritized curriculum contents is self-development which is part of the self-adjustment process in learning to be social at school, which is realized through extracurricular and extracurricular activities. Extracurricular self-development is in the form of Counseling Guidance and Educational Visits. Meanwhile, extracurricular include Scouting, Islamic Arts, Sports, and Life Skills.

Table 1. Data of Teachers at Ar-Risalah Islamic College Junior High School

\begin{tabular}{llll}
\hline & Male & Female & Total \\
\hline Teacher & 19 & 29 & 48 \\
\hline
\end{tabular}

Table 1 shows that Ar-Risalah Islamic College Junior High School consists of 48 teachers, with 19 males and 29 females. According to the administrative staff, on average, the teachers possess an undergraduate degree from UNAND (Andalas University), 
UNP (Padang State University), and IAIN (Islamic State Institute) Padang.

Table 2. Data of Students at Ar-Risalah Islamic College Junior High School

\begin{tabular}{ccc}
\hline Class & Total Students & $\begin{array}{c}\text { Total Learning } \\
\text { Groups }\end{array}$ \\
\hline I & 192 & 6 \\
II & 184 & 6 \\
III & 171 & 6 \\
TOTAL & 547 & 18 \\
\hline
\end{tabular}

Table 2 shows that there are 547 students categorized under 18 study groups.
Classes I, II, and III consist of 192, 184, and 171 students, placed under 6 study groups, respectively. The habituation initiative at the Ar Risalah Islamic College is called the dormitory program, which includes character, moral and religious development of students continuously carried out and programmed in accordance with a descriptive routine. The spontaneous and exemplary activities of habituation and dormitory program are shown in Table 3.

Table 3. Habituation/Dormitory Program

\begin{tabular}{lll}
\hline \multicolumn{1}{c}{ ROUTINE } & \multicolumn{1}{c}{ SPONTANEOUS } & \multicolumn{1}{c}{ EXEMPLARY } \\
\hline Flag ceremony & $\begin{array}{l}\text { Greeting other people during } \\
\text { meetings } \\
\text { Tidy up sandals and shoes }\end{array}$ & Pray on time \\
$\begin{array}{l}\text { Gymnastics } \\
\text { Read 2 pages of the Qur'an daily } \\
\begin{array}{l}\text { Memorize the Qur'an at least 1 } \\
\text { page per week }\end{array}\end{array}$ & $\begin{array}{l}\text { Exhibit Islamic behavior } \\
\text { Communicate in English or Arabic } \\
\begin{array}{l}\text { Pray before and after studying } \\
\text { Perform prayer sessions 5 times } \\
\text { in the congregation }\end{array}\end{array}$ & $\begin{array}{l}\text { Say good words } \\
\text { Give compliments }\end{array}$ \\
\hline
\end{tabular}

This program is routinely performed at the Ar Risalah Islamic College. It involves all the teachers and caregivers in the dormitory as well as all the extended family members of the Ar Risalah Waqf Foundation. In addition, the students are given all forms of homework (PR). Ar-Risalah Islamic College has boarding facilities, therefore asides from academics, students also participate in parenting activities in the dormitories. This ensures the available time is arranged as effectively as possible, including PR. Nevertheless, homeworks are given after teaching the subjects that need continuous practice, such as Mathematics, Science, Religion, and Information and Communication Technology, with a maximum time consideration of $1 / 4$ of the face-to-face hours per week. Meanwhile, the teachers handling other subjects are advised not to give homework.

\section{The Teachers' Role in Increasing Self- Adjustment}

Based on the interviews with teachers and caregivers, students' self-adjustment to the new environment varies. The majority adapt quickly, while some others are slow. Those that adapt quickly are usually able to adjust to their new environment within a month. Meanwhile, it takes some others 3 months or more to be able to adjust to the new environment. This is evident in the results of the interviews with the teachers and caregivers, which are stated as follows:

...some students adapt quickly, while some are slow, and this takes a month or even longer,... (Hi, W1, 05-112014, M: 11-17)......this process requires a maximum of 3 months. However, some students slowly adapt to the new environment ( $R$ and $\mathrm{He}$, W4, 07-11-2014, L: 30-33) ....they need at least 3 months because that is the adaptation period $(F, W 2,05-11$ 2014, L: 37-38).

New students with slow selfadjustment usually exhibit certain behaviors such as crying, difficulty sleeping, always sickly, being alone, and not wanting to communicate with others. This is reported in the results of interviews with teachers and caregivers.

Students with slow self-adjustment tend to cry, find it difficult to sleep, and are always sick because they miss their parents (Hi, W1, 05-11-2014, M: 106- 
110). These students usually long for their parents, hence they tend to cry,... (R and He, W4, 07-11-2014, L: 21-27).

Behaviors such as crying, difficulty sleeping, being sickly, secluded, and not wanting to communicate with other people emerge because they miss their homes. This is normal and natural for every new student because they have never been separated from their parents. This is evident from the results of the interviews, which are reported as follows:

...new students cry because they miss home, this is normal because they have never been separated from their parents ( $R$ and He, W4, 07-11-2014, M: 60-64).

The teachers try to help with the process of self-adjustment to the new environment. First, the school organizes a Student Orientation Period (MOS) to help them get to know their new environment. They are introduced to new friends, seniors, ustadz and ustadzah, classrooms, laboratory, etc. The results of the interview with the teachers (deputy head of curriculum) are reported as follows:

...Before lessons commerce, an activity called the Student Orientation Period (MOS) is held. During the MOS, they get to know their environment, make new friends, are introduced to the seniors, ustadz, and ustadzah... The MOS committee also introduces them to other facilities such as the laboratories and classrooms....including culture, rules, organization, and several other activities....This lasts for a week and at the end, there is usually an outbound to lighten the atmosphere... (Hi, W1, 05-11-2014, L: 49-85).

Second, the school organizes training sessions for all homeroom teachers every new academic year, with the aim that they are able to solve certain problems encountered by the students, especially the new ones. The following is an interview excerpt.

The school always holds training sessions for all homeroom teachers every new academic year, to understand every problem faced by students, especially the new ones... (Hi, W1, 05-11-2014, M: 203-208)

The training given to new teachers is known as Intensive Teaching Learning (ITL), and it lasts for 7 days. During this process, they are introduced to the foundation, its history, the existing structures, and ways to handle certain problems faced by the students....(D, W3, 07-11-2014, M: 380-386)

Third, dormitory caregivers (musyrif) also play a role in helping the new students' self-adjustment process. For example, the caregivers (musyrif) approach, persuade, and advice any new student crying. An interview excerpt is reported as follows

...they persuade and talk to them and assuming they are unable to handle the situation, then they communicate with their parents... (F, W2, 05-11-2014, M: 88-99)

...they are encouraged and motivated. (R and $\mathrm{He}, \mathrm{W4}, 07-11-2014, \mathrm{~L}:$ 73-77). ...However, when any of them remembers their parents, they are told to read the Qur'an because at that time they are being tempted by Satan... (M \& HR, W5, 18-11-2014, L: 10-15).

Fourth, the caretaker conducts training sessions for new students to provide motivation and reinforcement, enabling them to adjust to the new environment. The following is an excerpt from an interview with a female caregiver (Musyrifah)

...First, the students, are undergoing a training session for only 2 days, to motivate and strengthen them, thereby increasing their survival and adaptation rate ... (I'm, W7, 23-102014, L: 20-25)

In terms of learning patterns, ArRisalah Islamic College Junior High School implemented a boarding facility, meaning that all students are expected to live in the dormitory to participate in learning and parenting activities in the hostel. These are admittedly dense, such as congregational 
prayers, memorizing the Koran, halaqah, mentoring, and other time and energyconsuming procedures.

However, when viewed from the students' perspectives, especially in terms of affective and psychomotor abilities, the activities carried out by Ar-Risalah Junior High School are considered forced. In terms of affective abilities, hindering a 12-year-old's emotional attachment to their parents causes the majority to cry in their early days at school. Likewise, the psychomotor ability, the students feel forced to carry out several activities. Based on interviews with several teachers, it was concluded that in the first month, they obey set rules because the environment has not yet contaminated them. However, after a while, they start to disobey some burdensome activities, including congregational prayers, where the priest reads long verses close to one page of the Koran.

On Tuesday, November 18, 2014, the observation activity disclosed that whenever the teachers passed the new students, they greeted and briefly interacted with them. A similar attitude was also exhibited when they met with caregivers. Regarding the relationship with the senior students, it appears that they studied together and interacted in English. Likewise, the same language was used to play with friends, and they did not seem to fight. Based on the observations in the dormitory, it was discovered that students obey set rules, such as taking a cold shower in the large bathroom provided.

The closeness between teachers and new students strengthens their relationship. This means that the role of assisting them in developing self-adjustment establishes the distance between them. The classic reason is that it triggers the teachers' authority according to the students' perspective. However, it doesn't make sense because they act as second parents, enabling them to discuss their condition with the teachers directly. Based on their roles and responsibilities, they need to listen to each student's complaints. This classic reason does not apply to Ar-Risalah Islamic College Junior High School because the relationship between teachers and students is similar to that between children and parents.

This subject matter has a boring characteristic because it requires concentration because even though the teachers are talented and proficient in delivering and presenting the lesson, the students' brains are still limited in terms of absorbing the study material. Therefore, the educators are allowed to include sideline jokes to eliminate the boredom in the classroom atmosphere due to the numerous activities (Kasmar et al., 2019; Maya, 2017). The various interactive processes in social life, especially in the dormitory, help them to be able to adapt and adjust to their environment. In psychology, this principle is called selfadjustment, which means to adapt to ones' demands and needs in a social environment (Hastiani et al., 2020).

Based on observations made, both in and outside the classroom, such as dormitories and around the college, it seems like the students joke a lot with their teachers. Likewise, excerpts from interviews prove that socially, the relationship between teachers and students at the Ar-Risalah Islamic College is like water, they are cordial, compared to in other schools. A similar finding was also discovered in the relationship between caregivers and students in the dormitory. The following are excerpts from interviews with teachers and caregivers

...they have an extremely cordial
relationship with the students in Ar-
Risalah compared to other schools
(Hi, W1, 05-11-2014, L: 298-301).
...this is because they spend 24 hours
with the students, in class, and in the
dormitory. It seems that the frequent
meetings make them closer compared
to other schools. (Hi, W1, 05-11-2014,
$\mathrm{M}: 303-311$ ).

An inspiratory forum is held to channel their burdens to establish the intimacy between students and teachers, caregivers, and seniors. This activity relieves them of the pressure that results from mind splitting. This forum also serves to channel the students' desires to gain a positive impact on self-adjustment. This is 
because negative feelings that tend to disturb their minds are eliminated, and any emergent problem is properly resolved. In this case, teachers and caregivers willingly listen to their students' stories. The following is an excerpt from an interview with a caregiver (musyrifah) ...there is a forum to acquire ideas, afterward, a briefing is held with all the teachers... (F, W2, 05-11-2014, L: 328-331).

Teachers' attention is evident when any of the new students are sick, and they immediately visit them in the dormitory to ascertain their condition. This strengthens their relationship because they feel the teachers' presence aids them in recovering quickly. However, assuming the reverse is the case, they are taken to the clinic in Ar-Risalah for treatment, and the caregivers render extra services such as feeding them with milk. The teachers' and caregivers' roles, is similar to that of the new students' parents. Relating to their feeding, the caregivers usually have a meeting with the students once a month to discuss the type of food they like. This is to ascertain that the students enjoy the meals served by the kitchen staff daily. The following is an excerpt from an interview with a caregiver.

...especially for sick students, the teachers visit them in the dormitory to ascertain their condition and then take them to the clinic for treatment. Sometimes, caregivers feed them with milk... (F, W2, 05-11-2014, L: 284290)

...once a month, they are asked to discuss their favorite food. (F, W2, 0511-2014, L: 318-319)

Attention is also given to students that have just entered their teenage years, particularly those that are menstruating for the first time. Not everyone understands the signs of puberty, this is because the students come from different families and regions. They are also congratulated by their fellow students and caregivers that teach them to deal with problems regarding menstruation. The following is an excerpt from an interview with a caregiver. ...when students experience menstruation for the first time, they are congratulated by friends and ustadzah,... and are later taught ways to deal with puberty... (F, W2, 05-112014, L: 304-30)

\section{Inhibiting and Supporting Factors in the Students' Self-Adjustment Process}

Based on the subjects that were interviewed, the new students' self-adjustment is determined by 2 attributes, including supporting and inhibiting factors. Furthermore, supporting factors are positive qualities that help the self-adjustment process of new students. On the contrary, inhibiting factors are negative attributes that complicate this process. These 2 greatly affect the selfadjustment process of new students at the ArRisalah Islamic College, thereby ensuring they are able to survive and adjust to the new environment. Conversely, the majority are also unable to adapt and decide to leave school.

The supporting factors are manifested through a Student Orientation Period (MOS) activity for new students organized by the school. This is a guidance service to introduce them to the environment. It is carried out due to the assumption that adapting to a new environment is not usually a pleasant experience. This activity is important for the new students of Ar-Risalah Islamic College Junior High School to adapt to the new environment, friends, seniors, ustadz, ustadzah, etc.

They need to understand their surroundings as soon as possible. In this case, the physical environment (such as buildings, equipment, and other structural facilities), materials, condition of the activities (type and duration), regulations, various other provisions (namely discipline, rights, and obligations), existing personalities, duties assigned to each individual, etc needs to be considered (Hrich et al., 2019). These environmental conditions have an enormous impact on the students' selfadjustment process (Yuzarion et al., 2020).

The following is an excerpt from the interview with the teacher 
... During MOS activity, the students are given several tasks related to getting to know the environment, their friends, male and female seniors, ustadz..., certain facilities such as laboratories and classrooms.... in addition, they are introduced to the school culture, rules, organizations, and activities...(Hi, W1, 05-11-2014, L: 49-85).

Besides, there is a training program for each teacher at the beginning of the new academic year, aimed at teaching them ways to understand and deal with problematic students. Furthermore, new students are also given motivational training after spending a night in the dormitory (Bhati \& Song, 2019). In addition, a halaqah or mentoring program is routinely carried out once a month. The following is an excerpt from the interview with one of the teachers.

Halaqah or mentoring is a form of guidance for students in Islamic studies. They are divided into several groups consisting of 12 students. This activity is held once a week, particularly on Fridays at $10 \mathrm{am}$. (Hi, W1, 05-11-2014, L: 324-330)

The inhibiting factor that complicates the self-adjustment process is that students are inseparable from their parents. This inability is tolerated within the first and third months of resumption. However, the parents of those that are unable to adjust after the first 3 or even 6 months are invited to ascertain their continuity at the Ar-Risalah College. The following is an excerpt from the interview with a teacher

... A total of 3 new students left the school because of the same problem, namely being inseparable from their parents. (Hi, W1, 05-11-2014, L: 196200)

Contrarily, some parents are inseparable from their children due to feelings of loneliness. The following is an excerpt from an interview with a caregiver (musyrif) ...due to the strong inner bond, some parents wait for their children in the dormitories during the visit hours of
09 a.m to 5.30 p.m. In addition, when they see their children, they look at them for a long time irrespective of their desire to pray in the congregation at the mosque. This is an obstacle for the children's selfadjustment.

\section{CONCLUSION RECOMMENDATION}

AND

In conclusion, the roles and strategies adopted by teachers in developing the selfadjustment process of new students at ArRisalah Islamic College Junior High School Padang, during the student orientation period (MOS), which is usually carried out for 3 days at the beginning of every academic year, motivates them in adapting to the new environment. Students are always entertained weekly, either by watching movies together, swimming, and other recreational activities.

Other efforts carried out by teachers include holding regular meetings once a week and monitoring students during classes through attendance and homework. Students are also permitted to communicate with their parents and psychologists.

Some of the factors affecting students' self-adjustment are close attachment to their parents and vice versa, therefore their talents are not fully channeled, and caregivers do not have a psychological background.

\section{REFERENCES}

Alfaiz, A., Yandri, H., Yuzarion, Y., Lestari, L. P. S., \& Heriyani, E. (2019). Persepsi agentik individu untuk mencapai prestasi pribadi dalam aktivitas karir: Riset pendahuluan. Psychocentrum Review, 1(2), 85-95 https://doi.org/10.26539/pcr.1276.

Alfaiz, R. H. R., Triyono, M. D., \& Septya Suarja, N. (2020). Student Personal Agency Weakness in Autonomous Learning: Preliminary Research. International Journal of Innovation, Creativity and Chang, 13(7), 973-989. 
Anand, D., Gupta, V., Paruchuri, P., \& Ravindran, B. (2021). An Enhanced Advising Model In Teacher-Student framework Using State Categorization. Proceedings of the AAAI Conference on Artificial Intelligence, 35(8), 66536660.

Anggito, A., \& Setiawan, J. (2018). Metodologi penelitian kualitatif. CV Jejak (Jejak Publisher).

Baeten, M., \& Simons, M. (2014). Student teachers' team teaching: Models, effects, and conditions for implementation. Teaching and Teacher Education, 41, 92-110 https://doi.org/10.1016/j.tate.2014.03. $\underline{010}$.

Bhati, A., \& Song, I. (2019). New methods for collaborative experiential learning to provide personalised formative assessment. International Journal of Emerging Technologies in Learning, 14 , 179-195 https://doi.org/10.3991/ijet.v14i07.917 $\underline{3}$.

da Costa, A., Hanurawan, F., Atmoko, A., \& Hitipeuw, I. (2018). The impact of selfadjustment on academic achievement of the students. ISLLAC: Journal of Intensive Studies on Language, Literature, Art, and Culture, 2(1), 16 http://dx.doi.org/10.17977/um006v2 i12018p001.

Gimenez-Serrano, S., Garcia, F., \& Garcia, O. F. (2021). Parenting styles and its relations with personal and social adjustment beyond adolescence: Is the current evidence enough? European Journal of Developmental Psychology, $1-21$

https://doi.org/10.1080/17405629.202 $\underline{1.1952863}$

Halik, A. (2016). Paradigm of Islamic Education in the Future: The Integration of Islamic Boarding School and Favorite School. Information Management and Business Review, $8(4)$, https://doi.org/10.22610/imbr.v8i4.13 90.

Hasanah, U., \& Usman, O. (2020). The Influence of Self-Concept, Self Efficacy, and Social Support on Adjustment of Self-Students in the Process of Teaching Learning Activities. Self Efficacy, and Social Support on Adjustment of Self-Students in the Process of Teaching Learning Activities (June 29, 2020) http://dx.doi.org/10.2139/ssrn.3 $\underline{637787 .}$

Hastiani, H., Ramli, M., Saputra, R., Alfaiz, A., Suarja, S., Mulyani, R. R., \& Aulia, R. (2020). Saprahan as Indigineous Value to Maintain Self-Identity of Adolescents in Pontianak Region. Acta Counseling and Humanities, 1(1), 4252

https://doi.org/10.46637/Ach.V1i1.11.

Hrich, N., Lazaar, M., \& Khaldi, M. (2019). Improving Cognitive Decision-Making into Adaptive Educational Systems through a Diagnosis Tool based on the Competency Approach. IJET, 14(7), 226-235 https://doi.org/10.3991/ijet.v14i07.987 0 .

Ikhwan, A., Farid, M., Rohmad, A., \& Syam, A. R. (2020). Revitalization of Islamic Education Teachers in the Development of Student Personality. 1st Borobudur International Symposium on Humanities, Economics and Social Sciences (BIS-HESS 2019), 162-165.

Japar, M. (2014). Religiousity, Spirituality and Adolescents' Self-Adjustment. International Education Studies, 7(10), 66-73 DOI: $10.5539 /$ ies.v7n10p66

Kadafi, A., Alfaiz, A., Ramli, M., Asri, D. N., \& Finayanti, J. (2021). The Impact of Islamic Counseling Intervention towards Students' Mindfulness and Anxiety during the COVID-19 Pandemic. Islamic Guidance and Counseling Journal, 4(1), 55-66 
https://doi.org/10.25217/igcj.v4i1.101 8

Karadağ, M., Altınay Aksal, F., Altınay Gazi, Z., \& Dağli, G. (2020). Effect size of spiritual leadership: In the process of school culture and academic success. SAGE Open, 10(1), 2158244020914638 https://doi.org/10.1177/215824402091 4638.

Kasmar, I. F., Amnda, V., Mutathahirin, M., Maulida, A., Sari, W. W., Putra, S., Anwar, F., Taufan, M., \& Engkizar, E. (2019). The Concepts of Mudarris, Mu'allim, Murabbi, Mursyid, Muaddib in Islamic Education. Khalifa: Journal of Islamic Education, 3(2), 107125 http://dx.doi.org/10.24036/kjie.v3 i2.26.

Li, Y., Wen, Z., Cao, Y., Tan, Y., Sidorov, D., \& Panasetsky, D. (2017). A combined forecasting approach with model selfadjustment for renewable generations and energy loads in smart community. Energy, 129, 216-227 https://doi.org/10.1016/j.energy.2017. $\underline{04.032 .}$.

Maya, R. (2017). Menuju Pendidikan Islam Berbasis Al-Ittibā'. Edukasi Islami: Jurnal Pendidikan Islam, 2(04) http://dx.doi.org/10.30868/ei.v2i04.41.

Metzger, Z. (2014). The self-adjusting file (SAF) system: An evidence-based update. Journal of Conservative Dentistry: $\quad J C D, \quad 17(5), \quad 401$ doi: $\underline{10.4103 / 0972-0707.139820 .}$.

Moleong, L. J. (2021). Metodologi penelitian kualitatif. PT Remaja Rosdakarya.

Musaddad, A. (2021). Organizational Culture In The Islamic Boarding School: Phenomenology Review. AL-TANZIM: Jurnal Manajemen Pendidikan Islam, $5(1)$, 154-164 http://doi.org/10.33650/altanzim.v5i1. 1982.

Na, H., Dancy, B. L., \& Park, C. (2015). College student engaging in cyberbullying victimization: Cognitive appraisals, coping strategies, and psychological adjustments. Archives of Psychiatric Nursing, 29(3), 155-161 https://doi.org/10.1016/j.apnu.2015.01 .008 .

Naziah, R., Caska, C., Nas, S., \& Indrawati, H. (2020). The Effects of Contextual Learning and Teacher's Work Spirit on Learning Motivation and Its Impact on Affective Learning Outcomes. Journal of Educational Sciences, 4(1), 30-43 https://doi.org/10.31258/jes.4.1.p.3043.

Noviandari, H., \& Mursidi, A. (2019). Relationship of Self Concept, Problem Solving and Self Adjustment in Youth. International Journal for Educational and Vocational Studies, 1(6), 651-657 https://doi.org/10.29103/ijevs.v1i6.15 99.

Pasi, K. M., Rasyidin, R., \& Harahap, R. M. (2020). Education System of Modern Islamic Boarding School in The Postmodern Era. Nazhruna: Jurnal Pendidikan Islam, 3(3), 311323 https://doi.org/10.31538/nzh.v3i3 $\underline{.805}$.

Rahawarin, Y., Hakim, R., Sari, W. W., Ramdani, N. S., Kasmar, I. F., Wulandari, S., Restari, Y. A., Amnda, V., \& Arifin, Z. (2020). Seven Motivations of Students Selecting Department of Islamic Teaching Education in Public University. Asian Social Science and Humanities Research Journal (ASHREJ), 2(1), 4555

https://doi.org/10.37698/ashrej.v2i1.2 $\underline{5}$.

Rukin, S. P. (2019). Metodologi Penelitian Kualitatif. Yayasan Ahmar Cendekia Indonesia.

Sokip, S., Akhyak, A., Soim, S., Tanzeh, A., \& Kojin, K. (2019). Character building in islamic society: A case study of muslim families in Tulungagung, East Java, 
Indonesia. Journal of Social Studies Education Research, 10(2), 224-242.

St-Charles, P.-L., Bilodeau, G.-A., \& Bergevin, R. (2015). A self-adjusting approach to change detection based on background word consensus. 2015 IEEE Winter Conference on Applications of Computer Vision, 990997 DOI: 10.1109/WACV.2015.137.

Sugiyono, M. (2015). Penelitian \& pengembangan (Research and Development/R\&D). Bandung: Penerbit Alfabeta.

Sultana, M. (2014). Ethics in teaching profession. ABC Journal of Advanced Research, 3(1), 44-50 https://doi.org/10.18034/abcjar.v3i1.3 $\underline{1 .}$

Toharudin, U., Rahmat, A., \& Kurniawan, I. S. (2019). The important of self-efficacy and self-regulation in learning: How should a student be? Journal of
Physics: Conference Series, 1157(2), 022074 doi:10.1088/17426596/1157/2/022074.

Usman, O., \& Hasna, K. (2019). Influence of Motivation, Facilities and Infrastructure, Self-Efficacy, SelfAdjustment to Learning Independence. Facilities and Infrastructure, SelfEfficacy, Self-Adjustment to Learning Independence (December 31, 2019) http://dx.doi.org/10.2139/ssrn.3 512128.

Yuzarion, Y., Agustiana, A. K., Alfaiz, A., Yandri, H., Musdizal, M., \& Aulia, R. (2020). Learning achievement reviewed from self regulated learning, future orientation, and parental support. COUNS-EDU: The International Journal of Counseling and Education, 5(2), 71-80 https://doi.org/10.23916/00202005268 20. 